РОЗДІЛ 8. ТЕОРІЯ НАВЧАННЯ

\author{
НЕВЕРБАЛЬНІ ЗАСОБИ СПІЛКУВАННЯ В АСПЕКТІ \\ МОВНОЇ ПІДГОТОВКИ ІНОЗЕМНИХ СТУДЕНТІВ \\ NON-VERBAL MEANS OF COMMUNICATION IN THE ASPECT \\ OF LANGUAGE TRAINING OF FOREIGN STUDENTS
}

УДК 371.13.81

DOI https://doi.org/10.32843/2663-

$6085 / 2021 / 39.56$

\section{Рязанцева Д.В.}

канд. фрілол. наук,

доцент кафедри мовної підготовки

Харківського національного

автомобільно-дорожнього університету у статті розглядаються невербальні засоби спілкування в аспекті мовної підготовки іноземних студентів, досліджуються сутність невербальних засобів спілкування, їхня значущість у вивченні української мови й акультурації іноземних студентів. Розглядається національний френомен жестової мови, жести як одна 3 форм пізнання культури, традицій того чи іншого народу, явище лінгвоцентризму. Охарактеризовано відмінності вербальних та невербальних засобів комунікаціі, паралінгвістичних (темпо-ритмічні та мелодико-інтонаційні особливості мови); екстралінгвістичних (сміх, плач, зітхання, цокання); проксемічних (просторові пересування під час занять); кинесичних (міміка, жести, пантоміміка) засобів спілкування. Аналізуються завдання, які постають перед викладачами мовних дисциплін, що працюють з іноземними студентами, в аспекті іхньої мовної підготовки. Розглядаються думки різних дослідників щодо даної проблеми. Визначаються прийоми роботи з іноземними студентами з урахуванням їхнього культурного досвіду, подається опис цікавих засобів невербального спілкування, що можуть бути використані для фрормування ефективної взаємодії викладача вищої школи з іноземними студентами на заняттях із мовної підготовки.

у статті наголошується, що розуміння чужої культури через мову передбачає вихід за рамки лексики, граматики і синтаксису. Крім того, під час роботи з іноземними студентами необхідно враховувати і релігійну приналежність учнів, оптимальну відстань між співрозмовниками, прийняту в культурі студента. Зроблено наголос на тому, що семантика жестів, декодування невербальної складової частини спілкування виступають передумовою більш глибокого розуміння змісту повідомлення.

Окреслено перспективність наукових пошуків у цьому напрямі. Матеріали статmі можуть бути використані для позааудиторної роботи з іноземними студентами, що навчаються в Україні.

Ключові слова: невербальне спілкування, комунікація, мова, акультурація, іноземні студенти.

The article considers non-verbal means of communication in the aspect of language training of foreign students, investigates the essence of non-verbal means of communication, their significance in the study of the Ukrainian language and acculturation of foreign students. The national phenomenon of sign language, gestures as one of the forms of knowledge of culture, traditions of this or that people, the phenomenon of linguocentrism is considered. Differences of verbal and nonverbal means of communication, paralinguistic (tempo-rhythmic and melodic-intonational features of language) are characterized as well as extralinguistic (laughter, crying, sighing, tickling); proxemic (spatial movements during classes); kinesic (facial expressions, gestures, pantomime) means of communication.

The tasks faced by teachers of language disciplines working with foreign students in terms of their language training are analyzed. Opinions of various researchers of this problem are considered. The methods of working with foreign students are determined taking into account their cultural experience and a description of interesting means of non-verbal communication that can be used to form an effective interaction of a high school teacher with foreign students in language classes is given.

The article emphasizes that understanding a foreign culture through language requires going beyond vocabulary, grammar and syntax. In addition, when working with foreign students, it is necessary to take into account the religious affiliation of students, the optimal distance between interlocutors, accepted in the culture of the student. In the process of language training of foreign students, it is important both the teacher's understanding of the gestures used by students and the audience's adequate perception of non-verbal means used by the teacher. In interethnic communication, the issues of gesture semantics become especially important. The decoding of the non-verbal component of communication is also analyzed, which is a prerequisite for a deeper understanding of the content of the message.

The prospects of further scientific research in this direction are outlined. The materials of the article can be used for extracurricular work with foreign students studying in Ukraine. Key words: nonverbal communication, communication, language, acculturation, foreign students.
Постановка проблеми в загальному вигляді. Глобалізаційні тенденції, що мають місце в сучасному світі, $€$ найважливішими і найбільш впливовими процесами в нинішніх світових суспільних відносинах. Один з істотних проявів процесу глобалізації - взаємодія культур, їхній діалог - найбільш сприятлива основа для розвитку міжет- нічних, міжнаціональних відносин. Саме тому у процесі мовної підготовки іноземних студентів велику практичну значущість має вивчення невербальних компонентів спілкування.

Жестова комунікація значною мірою $є$ таким же національним френоменом, як і вербальні мови. Жести і міміка утворюють модель комунікації, 
яку можна порівняти 3 моделлю поведінки. Відповідність використовуваних засобів невербальної комунікації цілям і змісту словесної передачі інорормації - один із важливих елементів культури спілкування. Ця відповідність має особливу актуальність для викладача, який працює з іноземним контингентом учнів, тому що в цьому разі засоби як вербальної, так і невербальної комунікації $€$ інструментом його профресійної діяльності.

Аналіз останніх досліджень і публікацій. Дослідження у сорері невербальної комунікації проводилися вітчизняними (А. Бодальов, В. Лабунська й інші) і закордонними вченими (М. Аргайл, К. Бердвістл, В. Біркенбіль, Е. Холл, П. Екман та інші). Найбільш повно особливості невербальної мови як специфрічної мови спілкування описані американським психологом Р. Харрісоном. Він характеризує невербальну мову як природну, первинну, правопівкульну, що має, на відміну від вербальної мови, не лінійну тимчасову послідовність, а просторово-часову цілісність. Вербальна мова $€$ вокально-звуковим явищем, легко кодується і декодується. Невербальна ж мова складається 3 різноманітних рухів (жести, експресія особи, погляд, пози, інтонаційно-ритмічні характеристики голосу, дотику), що пов'язані з мінливими психічними станами людини, її ставленням до партнера, із ситуацією взаємодії. Значна частина невербальної інформації взагалі не може бути переведена в код будь-якої мови без істотної втрати її сенсу для партнерів [1, с. 97].

Невербальна мова є відмітною рисою кожної культури. Вивчення мов жестів - одна з фрорм пізнання культури, традицій того чи іншого народу. Якщо кожна лінгвокультурна спільнота має свою специфічну модель динамічної поведінки, то неадекватне використання «своїх» жестів спілкування іноземнихстудентівукраїнською/російськоюмовою може призвести до нерозуміння змісту комунікації українським співрозмовником, отже, порушити мовний контакт. Завдання викладача - навчити студента адекватно брати участь у комунікації.

А. Асмолов зазначає, що сучасній освіті властивий лінгвоцентрізм - центрація на словах [1]. Потенціал невербальних засобів спілкування в освітньому процесі повною мірою не використовується. Проте застосування невербальних засобів спілкування (жести, міміка тощо) необхідне в освітньому процесі тоді, коли потрібно передати інформацію (часом без слів), повідомити про свою згоду або незгоду тощо.

$€$. Верещагін та В. Костомаров у монографії «Мова і культура» відзначають: «Під час вивчення нової культури іноземний учень не може обійтися без знайомства 3 національно-психологічними особливостями народу, вираженими в цій культурі. Те саме можна сказати і про викладача іноземної мови, який повинен враховувати національний психологічний склад і культуру учнів» [3, с. 31]. Отже, у викладанні української / російської мови як іноземної необхідно враховувати особливості невербальної поведінки іноземної аудиторії, планомірно та систематично знайомити 3 особливостями невербальних засобів спілкування в сучасній українській культурі.

Виділення не вирішених раніше частин загальної проблеми. Аналіз науково-педагогічної літератури свідчить про те, що серед викладачів ЗВО та науковців значущість невербальних компонентів спілкування досі розглядалася фррагментарно й залишається дискусійним питанням, а неналежна обізнаність у цій сорері спеціалістів вищої школи не відповідає потребам іноземних студентів, що навчаються в українських закладах вищої освіти, та не забезпечує реалізації мовленнєвої діяльності на необхідному рівні.

Мета статті. 3 огляду на вищезазначене сорормульована мета статті, яка полягає в теоретичному обґрунтуванні та висвітленні невербальних засобів спілкування в аспекті мовної підготовки іноземних студентів.

Виклад основного матеріалу. У процесі мовної підготовки іноземних студентів на різних етапах навчання викладач широко використовує невербальні засоби спілкування: паралінгвістичні (темпо-ритмічні і мелодико-інтонаційні особливості мови); екстралінгвістичні (сміх, плач, зітхання, цокання); проксемічні (просторові пересування під час занять); кінесичні (міміка, жести, пантоміміка). Усе це, за твердженням дослідників, значно підвищує ефективність викладання іноземної мови, надає ситуативного характеру сприйняттю навколишнього світу [3, с. 49].

Розуміння чужої культури через мову вимагає виходу за рамки лексики, граматики і синтаксису, адже успішне пізнання чужої культури можливе лише тоді, коли водночас із вербальним процесом належна увагу приділяється і фроновим знанням, і етикетним нормам, що відображає дану культуру, культурі спілкування загалом. Чималий внесок у розуміння культури мови, що вивчається, вносить уміння правильно інтерпретувати невербальні вираження, якими користуються носії мови. Зазвичай труднощі у спілкуванні 3 іноземцями зумовлені незнанням елементарних основ міжкультурного спілкування.

Як вербальні мови відрізняються одна від одної залежно від типу культур, так і невербальна мова однієї нації відрізняється від невербальної мови іншої. У процесі мовної підготовки іноземних студентів важливим $€$ як розуміння викладачем жестів, використовуваних студентами, так і адекватне сприйняття аудиторією невербальних засобів, які використовуються викладачем. Під час міжнаціонального спілкування стають особливо значущими питання семантики жестів. Викладач 
української / російської мови як іноземної повинен орієнтуватися у країнознавчому матеріалі студентів, опанувати культурологічно цінну інорормацію про націю, із представниками якої він працює. Помилки в інтерпретації в основному спричинені формальним їх збігом: подібному жесту надається те значення, яке він має у своїй культурі.

Жести й інші засоби невербального спілкування можна декодувати неправильно з багатьох причин: національно-культурної специяріки; багатозначності; обмеженого соціального досвіду тощо. Фернандо Пойатос ілюструє цю тезу на прикладі декодування кінесичної складової частини спілкування:

1. Кінесичні засоби сприймаються, проте декодуються неправильно внаслідок цілковитої або часткової подібності динамічних малюнків і значень жесту.

2. Кінесичні засоби сприймаються, але не декодуються, оскільки не викликають візуальної асоціації з кінесичної системою рідної мови; наприклад, відтягування нижньої повіки вказівним пальцем у німців, іспанців означає «я все бачу», «я напоготові».

3. Кінесичні засоби не помічаються, оскільки представник іншої культури не підозрює, що вони несуть якесь значення; так, у Гонконзі постукування середнім і вказівним пальцем по столу означає подяку за те, що налили чай або вино.

4. Кінесичні засоби сприймаються, але декодуються неправильно внаслідок подібності динамічних малюнків у рідній та іншомовній культурах, але різниці у значеннях; так, жест "о'kay", що виконується не у вертикальній, а в горизонтальній площині, означає у французькому соціумі «нуль, порожнє місце» [4, с. 263].

Адекватне декодування невербальної складової частини спілкування виступає передумовою більш глибокого розуміння змісту повідомлення.

Наприклад, в українській, російській традиції піднятий вгору вказівний палець означає число «один». Якщо палець піднятий вертикально вгору, то це пов'язано з бажання мовця акцентувати увагу на промовлянні думки («стоп!», «увага!»). Прикладений до губ вказівний палець означає «тихо». Якщо водночас палець покачати з боку в бік, цей жест означатиме відмову. Трохи нахилений уперед палець, що хитається вгору й униз, означає загрозу або повчання

Для позначення цифр у різних культурах можуть використовуватися різні пальці. У Китаї рахують на пальцях, починаючи 3 великого, а в Україні з мізинця. Для зображення числа «три» українець і росіянин показують великий, вказівний і середній пальці, а китайці вказівний, середній і безіменний. Підняті і розведені в боки вказівний і середній пальці можуть позначати число «два», а в англомовних країнах можуть бути знаком перемоги ("victory"), символом першої літери цього слова. У російській і китайській аудиторії цей знак
$€$ еквівалентним, його значення буде зрозуміле у процесі комунікації. Жест, коли розставлені в боки великий палець і мізинець, а вказівний середній і безіменні пальці зібрані до долоні, у китайців позначає число «шість». Якщо водночас в українців і росіян пальці прикладаються до вуха, то цей жест означає прохання «подзвонити / передзвонити». Число «7» у Китаї передається за допомогою складених разом великого, вказівного і середнього пальця, тоді як безіменний і мізинець зігнуті до долоні. В Україні та Росії цей жест символізує релігійний знак «триперстя», який використовується в церкві. У китайців виставлення великого пальця вгору і вказівного пальця вперед означає число «вісім». В Україні і Росії даний жест радше сприймається як «пістолет». Жестом для позначення числа «десять» у Китаї служить зігнутий до половини вказівний палець, водночас інші зібрані до долоні. В українців і росіян цей жест пов'язаний із поняттям «гак, гачок» або дієсловом «підчепити».

Викладачеві необхідно також контролювати використання міміки і враховувати національну специоріку міміки студентів, щоб уникнути комунікативних невдач і адекватно зрозуміти студента. Мімічні рухи, як-от насуплені брови, широко розкриті очі, відкритий рот, надуті губи, стиснуті губи, підморгування тощо, мають фріксовані культурно зумовлені значення. Емоційні категорії, як-от гнів, радість, печаль або огида, є лінгво і культурно специорічними. У китайській аудиторії викладачеві необхідно пам'ятати, що в Китаї підняті брови знак гніву, тоді як в Україні та Росії піднімають брови частіше від подиву. У спілкуванні в аудиторії нігерійських студентів можлива ситуація, коли в разі осудження за будь-який учинок у відповідь викладачеві студент буде зображувати на обличчі усмішку або навіть сміятися, так він буде висловлювати своє зніяковіння, співчуття. Посмішка і легкий сміх у деяких країнах Африки є проявом подиву.

Використання жестів викладачем на етапі адаптації студентів має бути строго реґламентованим, оскільки в цей період учні не мають досвіду спілкування і відчувають культурний шок. Жести є культурно маркованими, так, кільце з великого і вказівного пальця студенти із США і більшості країн Європи сприймають як «ОК» («усе гаразд»); студенти з Південної Америки і Східної Європи цей знак можуть зрозуміти як «отвір»; учнями з Туреччини цей жест буде сприйнятий як сексуальна образа; для вихідця з Тунісу цей жест «з кільцем» означає щось на зразок «я тебе вб'ю».

У роботі з іноземними студентами необхідно враховувати і релігійну приналежність учнів, оскільки якщо в Україні не надається особливого значення тому, якою рукою щось робиться, то в тих, хто сповідує іслам, ліва рука вважається нечистою. Якщо ви даруєте подарунок або даєте гроші лівою рукою, ви можете образити мусульманина. 
У різних культур існують різні уявлення про оптимальні відстані між співрозмовниками. Так, китайці, монголи, жителі Північної Європи вважають за краще під час спілкування дотримуватися відстані із співрозмовником, на відміну від арабів, для яких 60 см - уже досить велика відстань для спілкування. Араби, жителі Східної Європи і середземноморських країн також досить активно використовують дотики під час спілкування. Англосаксонські народи вважаються людьми, які рідко користуються дотиками у спілкуванні. В азіатських культурах через дотик передаються почуття патронування і переваги. Дотик до плечей означає в цій культурі дружбу. Виявом братства серед мусульман є обійми. Але є і свої заборони: в азіатських культурах не можна торкатися голови співрозмовника, це розглядається як образа. Тому в азіатських культурах учителі часто б'ють учнів по голові, учні сприймають це як образливе покарання [3, с. 79-80].

Висновки. Вивчення невербальної комунікативної поведінки є одним із головних компонентів під час фрормування міжкультурної компетенції, інакше кажучи, у процесі опанування невербальних компонентів носіїв мови, що вивчається, іно- земні студенти вчаться сприймати інокультурні фракти, розуміти чужу культуру, бачити поведінку її носіїв їхніми очима.

Репрезентоване дослідження не вичерпує всього кола питань, пов'язаних із вивченням невербальних засобів комунікації в підготовці іноземних студентів, що зумовлює необхідність нових досліджень виокремленої проблеми та розроблення методичних рекомендацій щодо поліпшення вивчення культури іноземних студентів, створення комплексів навчально-методичного забезпечення для полегшення комунікації іноземних студентів в Україні.

\section{БІБЛІОГРАФІЧНИЙ СПИСОК:}

1. Асмолов А. За межею раціональності : лінгвоцентризм та парадокси невербальної комунікації. Київ : Азео, 1998. 123 с.

2. Верещагин Е. Язык и культура: Лингвострановедение в преподавании русского языка как иностранного. Москва : Наука, 1983. 234 с.

3. Хол Е. Як зрозуміти іноземця без слів. Київ : Молодий вчений, 1995. 197 с.

4. Fernando P. The reality of multichannel communication. The reality of multichannel verbal-nonverbal communication in simultaneous and consecutive interpretation. 1986. Vol. 1. P. 249-282. 